\title{
Short Communication: Two newly recorded species of Agaricales (Basidiomycota) from Banggai Kepulauan, Sulawesi, Indonesia
}

\author{
ATIK RETNOWATI ${ }^{\boldsymbol{\nu}}$, ANNE KUSUMAWATY, ISMAIL APANDI, AGUS HARYADI \\ Herbarium Bogoriense, Botany Division, Research Center for Biology, Indonesian Institute of Sciences. Jl. Raya Jakarta-Bogor Km. 46, Cibinong, Bogor \\ 16911, West Java, Indonesia. Tel.: +62-21-8765066, Fax.: +62-21-87907612, `email: marasjamur@gmail.com
}

Manuscript received: 9 October 2020. Revision accepted: 16 November 2020.

\begin{abstract}
Retnowati A, Kusumawaty A, Apandi I, Haryadi A. 2020. Short Communication: Two newly recorded species of Agaricales (Basidiomycota) from Banggai Kepulauan, Sulawesi, Indonesia. Biodiversitas 21: 5615-5621. Two species of Agaricales are reported here as new records for Indonesia, Mycena picta (Fr.) Harmaja (Mycenaceae) and Inocybe stellata E. Horak, Matheny \& Desjardin (Inocybaceae). These new records will contribute to the information on mushroom diversity in Indonesia. Mycena picta is characterized by having cylindrical and olive pileus; adnate to slightly decurrent and distant lamellae; filiform, greyish-yellow to dull yellow stipe. Inocybe stellata is distinguished by having brown conical pileus with squamules surface; adnexed or sinuate and close lamellae with 2 series of lamellulae; terete, glabrous with finely pruinose, base slightly bulbous, light brown stipe; echinulate, globose or subglobose basidiospores; metuloid hymenial cystidia and caulocystidia present. Photographs, descriptions, and line drawings of both macroscopic and microscopic features of the new records are provided herein and give a brief discussion on their taxonomy.
\end{abstract}

Keywords: Inocybaceae, Mycenaceae, species diversity, taxonomy

\section{INTRODUCTION}

Agaricales is one order within Basidiomycota, which is one of the most well-known groups of mushrooms. The order has been traditionally classified into three suborders; Agaricineae, Boletineae, and Russulineae, consists of a total of 18 families with 230 genera (Singer 1986). While in recent advance of Basidiomycota classification, those three suborders were elevated to be order Agaricales, Boletales, and Russulales within the subphylum Agaricomycotina (Hibbett et al. 2007). Ecologically, the order plays significant roles as saprotrophs, parasitic, or mycorrhiza. Some species contain dangerous toxins, and some species are edible. They are diverse in form of pileus, lamellae, and stipe. They mostly grow on the ground in woods, on compost, in the lawns, or in parks, and other habitats.

Until recently, only limited information on the Agaricales of Indonesia has been published and it was mostly published the species from Java and Bali (Leveille 1844,1846; Moritzi 1845-1846; Zollinger 1844; Hennings 1900; Overeem and Overeem-de Haas 1922; Boedijn 1940; Desjardin et al. 2000; and Retnowati 2018). Publication on the diversity of Basidiomycota from other parts of Sulawesi was documented by Samuels et al. (1990), nonetheless, it has accommodated order Aphylloporales, family Ganodermataceae, Hymenochaetaceae, and Polyporaceae (Rivarden 1990). The report was made primarily based upon collections from equatorial rain forest of North Sulawesi during the Project Wallacea carried out in 1985. The mushrooms from the order Agaricales have not become the attention.
Banggai Islands is a group of islands, which is located in Central Sulawesi, Indonesia. The islands comprises Banggai, Bangkurung, Bangkalan, Peleng, as well as several small islands, and these islands are as a connection to the mainland of Sulawesi Island and the eastern Indonesian archipelago. Banggai Islands is divided into two districts, namely: Bangai Kepulauan (Bakalan, Peleng) and Banggai Laut (Banggai, Bangkurung, etc.). Most of the parts of the Banggai are lowland forests up to 800 above sea level. Meanwhile, Peleng and western parts of Bakalan represent the mangrove ecosystem, mainly along Peleng coastal area. A report on the flora and fauna diversity of the archipelago has been published by Rahmadi et al. (2014), but Agaricales have not been reported. As a part of a biodiversity survey to Banggai Islands conducted by the Research Center for Biology (LIPI) in 2019, mycological exploration was carried out. A species of Mycena and a species of Inocybe are reported here as new records for Indonesia.

The genus Mycena consists of approximately 500 species in the world (Kirk et al. 2008) and it is a cosmopolitan genus as saprobic or parasitic fungi. According to Largent (1988), the following were the defining characters of Mycena: a small to medium fruiting body, campanulate, transparent-striate, and moist pileus; adnate to adnexed, and often decurrent; some glutinous stipe; white basidiospores, diverticula elements of hyphae. Some species are known as bioluminescent mushroom and bioluminescence becomes an important taxonomic character to define certain species within the genus (Corner 1994).

Inocybe is well-known as an ectomycorrhizal mushroom and the genus has potential importance in 
forestry and forest ecology (Singer 1986). The genus is found associated with Dipterocarpaceae (Pradeep et al. 2016), Pinaceae, Fagaceae, and Salicaceae, Fabaceae (Matheny et al. 2012), Myrtaceae, and Tiliaceae (Horak 1980). It comprises between 500-700 species worldwide (Kirk et al. 2008, Matheny et al. 2009). Species in the family can be recognized by their small or medium fruiting body, conical to convex, fibrillose pileus, adnexed to adnate lamellae, typically appressed fibrillose stipe, often present of the veil in the young specimens, brown, smooth or angular basidiospores, present thick-walled and crystalencrusted cheilocystidia (Largent 1988). The genus contains some edible species, I. cutifracta Petch (tropical Asia) and I. jurana Pat. (Europe), and some are poisonous which produced muscarine (Singer 1986).

Species of both genera will be presented in this paper with the data on various morphological features and notes on each species.

\section{MATERIALS AND METHODS}

\section{Study area}

Biodiversity survey to Banggai Kepulauan, Central Sulawesi, Indonesia was conducted in 2019, as shown in Figure 1. Geographically, Banggai Kepulauan are located between $1^{\circ} 06$ '30 "LS-2 20 "00" LS and 122 40 "00" East Longitude- $124^{\circ} 13^{\prime \prime} 30^{\prime \prime}$ East Longitude in the northeast of Sulawesi Island (Rahmadi et al. 2014). The specimens of Mycena and Inocybe were collected from Kokolomboi Hamlet, Leme-leme Darat Village, Buko Subdistrict and Kautu Hill, Salakan Village, Tinangkung Subdistrict, Banggai Kepulauan District, Central Sulawesi Province, Indonesia.

\section{Procedures}

The specimens of Agaricales were collected in Banggai Kepulauan by Purposive Random Sampling. An adequate number of basidiocarps were collected representing as many growth stages as were available in order to examine variability within the species. As needed, photographs were taken of suitable basidiocarps. Each collection was put in plastic boxes. If possible, spores prints were made in the field on white paper or on a microscope slide. Successful prints were usually obtained after about 24 hours, then spore print color was recorded. Notes on macromorphological features were made in the field soon after collecting, paying particular attention to: (i) size, shape, surface, color, and margin characteristics of different parts of the pileus; (ii) thickness, texture, color, taste, and odor of the flesh; (iii) presence or absence of a collarium; spacing, color and edge color of lamella; (iv) size, shape, color, and surface features of stipe; the attachment of the stipe to the substrate; (v) type of substrate; and (vi) the presence or absence of rhizomorphs. Brief notes were completed on fungus habit and habitat. Then collections were numbered and dried in the drier, afterward boxed, labeled, and stored, accompanied by a field label.

Macroscopic features were based on fresh material, while microscopic characters were described and illustrated using dried fungal specimens. Microscopic observation was made in material mounted in $3 \%$ of $\mathrm{KOH}$. The size of basidiospores was measured from the collections. Colour notation was determined using Kornerup and Wanscher (1978). Examined specimens are deposited in Herbarium Bogoriense (BO) of Botany Division, Research Center for Biology, Indonesian Institute of Sciences. Macroscopic and microscopic characters were compiled and presented here as a species description.
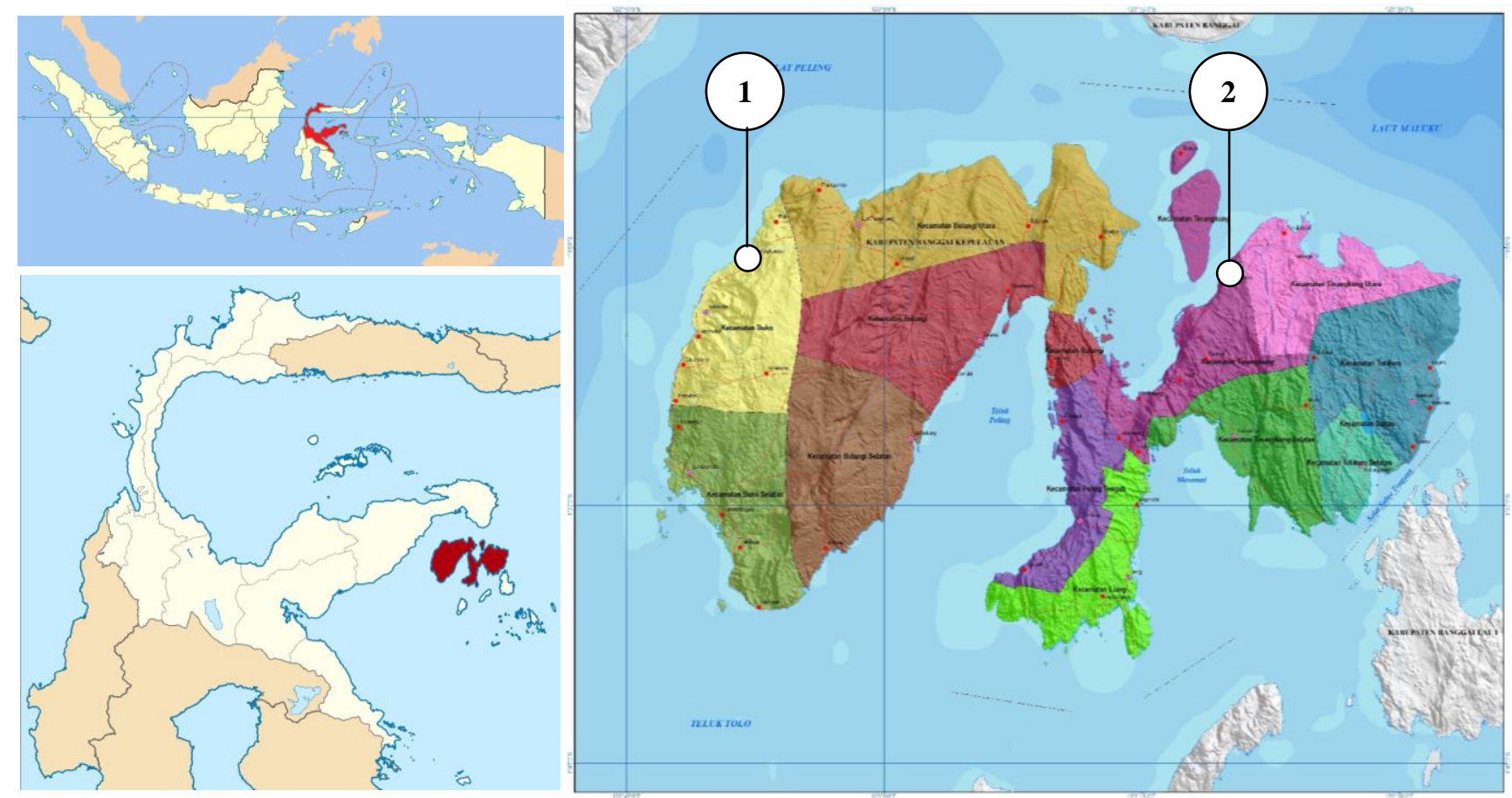

Figure 1. Sampling sites and locality of a biodiversity survey in Banggai Kepulauan District, Central Sulawesi, Indonesia (Badan Informasi Geospasial Republik Indonesia 2015-2019). Note: 1. Kokolomboi Hamlet, 2. Kautu Hill. 


\section{Data analysis}

The variations found on the morphological characters of the specimens were used as the primary data to identify them up to species level. The size, shape, color, and other features can be utilized for identification analysis. Identification of the materials can be performed based on agarics flora from several regions; East Africa (Pegler 1977), Lesser Antilles (Pegler 1983), and Srilanka (Pegler 1986). All line drawings of the micro-characters were made with the aid of a camera lucida attached to a compound microscope using $40 \times$ or $100 \times$ (oil immersion) objectives. Spore range was obtained by measuring 25 mature basidiospores. Basidiospore statistics include: the arithmetic mean of the spore length by spore width $( \pm$ standard deviation) for $\mathrm{n}$ spores measured in a single specimen $\left(\mathrm{x}_{\mathrm{m}}\right)$; the range of spore means $\left(\mathrm{x}_{\mathrm{mr}}\right)$, and the mean of spore means $( \pm S D)$ when more than one specimen is available $\left(\mathrm{x}_{\mathrm{mm}}\right)$; the quotient of basidiospore length and basidiospore width in any one basidiospore, indicated as a range of variation in $\mathrm{n}$ basidiospores measured $(\mathrm{Q})$; the mean of $\mathrm{Q}$-values in a single specimen $\left(\mathrm{Q}_{\mathrm{m}}\right)$; the range of $\mathrm{Q}_{\mathrm{m}}$-values where more than one specimen is available $\left(\mathrm{Q}_{\mathrm{mr}}\right)$; and the mean of $\mathrm{Q}_{\mathrm{m}}$-values where more than one specimen is available $\left(\mathrm{Q}_{\mathrm{mm}}\right)$ (Retnowati 2018).

\section{RESULTS AND DISCUSSION}

\section{Results}

Based on morphological features, the examined materials from Banggai Kepulauan were identified as Mycena picta (Fr.) Harmaja and Inocybe stellata E. Horak, Matheny \& Desjardin. These two species were confirmed as new records for Indonesia that have increased the number of reported species of the genus Mycena and Inocybe in Indonesia. According to Horak (1980), three species of Inocybe; I. fuscospinulosa Corner \& Horak, I. olorinata Horak, and I. subgeophylla Hennings apud
Warburg, were previously collected from Cibodas Botanical Garden, West Java, in 1972-1977. More additional records of three species of Inocybe, and eighteen species of Mycena, were from personal data of Retnowati (2019 unpublished data).

\section{Taxonomy descriptions and notes on each species}

Mycena picta (Fr.) Harmaja, Karstenia 19: 52. 1979. Figure 2-3.

Syn. Omphalia picta (Fr.) Gillet, Omphalina picta (Fr.) Quél., Xeromphalina picta (Fr.) A.H. Sm. (Maas Geesteranus 1983).

Fruiting body small. Pileus $2-4 \mathrm{~mm}$ diam, 2-4 mm high, cylindrical, greyish-yellow to dull yellow edges, flattened disc, glabrous, dry, translucent striate, olive. Context thin, pale olive. Odor and taste not distinctive. Lamellae adnate to slightly decurrent, distant (22 attached stipe), edges horizontal, greyish-yellow to dull yellow. Stipe 30-43 × $0.5 \mathrm{~mm}$, filiform, cylindrical, glabrous, greyish-yellow to dull yellow.

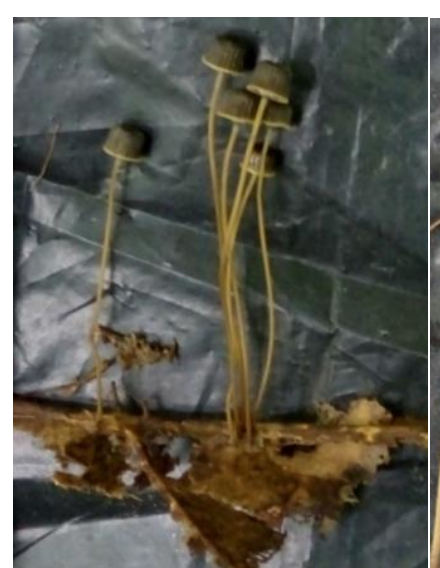

A

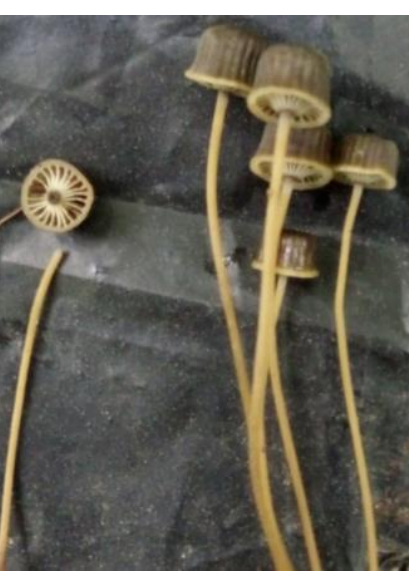

B
Figure 2. Mycena picta: A. Fruiting body, cylindrical and olive pileus; B. Lamellae (Photographs by: Idang Sumanta)

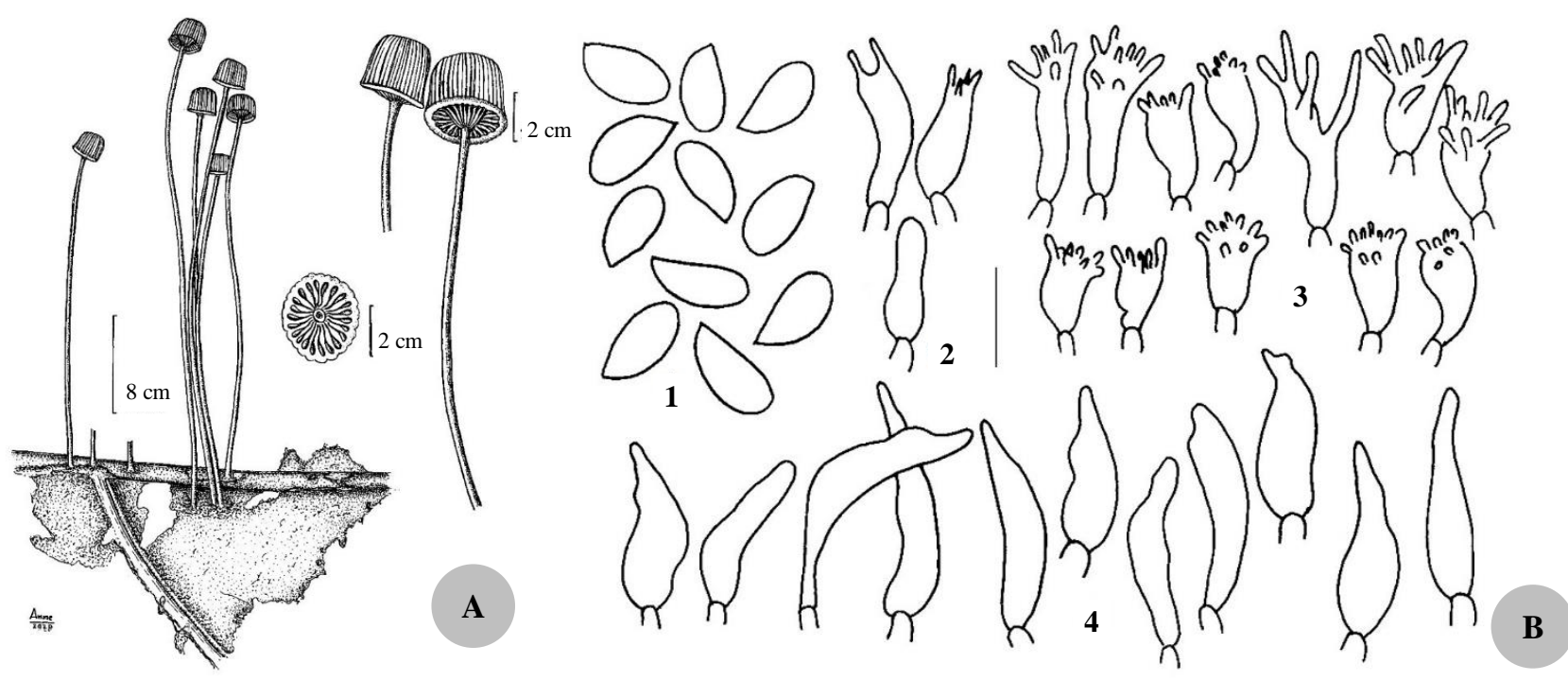

Figure 3. Mycena picta: A. Morphological characters of fruiting body (Drawn by A. Kusumawaty); B. Microscopic characters: 1 . Basidiospores; 2. Basidia and Basidioles; 3. Cheilocystidia; 4. Pleurocystidia. Scale bar: B1 = $10 \mu \mathrm{m}$; B2-B4 $=20 \mu \mathrm{m}$. Drawn by A. Retnowati from Banggai 79. 
Basidiospores 7.2-8.8 $\times$ 4.0-4.8(5.6) $\mu \mathrm{m}\left(\mathrm{x}_{\mathrm{m}}=8.16 \pm\right.$ $0.61 \times 4.38 \pm 0.41, \mathrm{Q}=1.50-2.20, \mathrm{Q}_{\mathrm{m}}=1.87 \pm 0.19, \mathrm{n}=25$ spores per 1 specimen), ellipsoid, thin-walled, hyaline, smooth, amyloid. Basidia 20-28 × 5.6-8.8 $\mu \mathrm{m}$, clavate, bearing 2-4-spored. Basidioles clavate. Pleurocystidia 28$40 \times 4.0-4.8(5.6) \mu \mathrm{m}$, common on sides, clavate to fusoid, or submucronate, hyaline, thin-walled. Cheilocystidia common, terminal cell forming Siccus-type broom cells; main body $12-32 \times 7.2-8.8 \mu \mathrm{m}$, cylindrical to clavate, often branched in the apical, hyaline to yellowish-brown; apical setulae $2.4-9.6 \times 0.8-1.8 \mu \mathrm{m}$, cylindrical to conical, obtuse, thin to thick-walled. Pileipellis a cutis; hyphae 2$8.5 \mu \mathrm{m}$ wide; hyphae $3.2-8.0 \mu \mathrm{m}$, thin-walled, hyaline to yellowish-brown. Stipe tissue monomitic; cortical and medullary hyphae undifferentiated, thin-walled, hyaline to yellowish-brown. Clamp connections present.

Habit, habitat, and distribution. Gregarious on dicot leaves in forest. Banggai Kepulauan (Sulawesi).

Material examined. Indonesia: Sulawesi, Central Sulawesi, Banggai Kepulauan, Peleng Island, Kokolomboi, 5 July 2019, Banggai 79, collected by Idang Sumanta.

Notes. Mycena picta is a member of Mycenaceae, and it was placed in section Pictae (A.H. Sm.) Maas Geest. of the genus Mycena (Pers.) Roussel. Macroscopic and microscopic characters confirm that the species belongs to the genus Mycena, following the generic concept of Singer (1975). Singer (1975) suggested that it belonged to Mycena or some other genus than Xeromphalina Maire. In addition, Harmaja (1979), Maas Geesteranus (1983), Miyamoto et al. (1996), and Halama and Romański (2010) placed it in the genus Mycena as Mycena picta (Fr.) Harmaja.

The cylindrical pileus is a distinctive character of the species with additional characters of centrally depressed, glabrous, translucent-striate, dark olive-gray (5Y-3/2) to olive-brown, pale yellow at the margin (Miyamoto et al. 1996). The species grows gregariously on several different kinds of substrate. In Japan and Finland, it is on needles of Abies sachalinensis Masters or Picea abies Karst. (Miyamoto et al. 1996) (Harmaja 1979), while in Poland, the species grew on dry but standing, the mossy trunk of black alder, in the phytocoenosis of Fraxino-Alnetum W. Mat. (Bujakiewicz 2002) and on the rotten stump of the coniferous tree (Halama and Romański 2010). In several areas in the world, M. picta is recognized as a rare species; United Kingdom (Latha and Manimohan 2017), Netherlands (Arnolds and Veerkamp 2008), Germany
(Benkert et al. 1992), Finland (Harmaja 1979). Bujakiewicz (2002) stated that in Poland this species should be classified as vulnerable (V).

Mycena picta has been reported from several regions, Finland (Harmaja 1979), Japan (Miyamoto et al. 1996), Poland (Halama and Romański 2010), Russia (2018). The species occurs in different areas and present variations of morphological characters (Table 1). However, the variations are within range of the existing characters. Poland materials have the biggest pileus and largest stipe compared to Indonesian, Japanese, or Finland materials. The biggest basidiospores are found in Japanese materials, and no different sizes of basidiospores of Indonesian, Poland, and Finland materials. Pleurocystidia is a presence in the Indonesian material only, and it is absent in Japan and Poland materials.

Inocybe stellata E. Horak, Matheny \& Desjardin, Phytotaxa 230(3): 215 (2015). - Type: A. Horak ZT10097, 1 Jul. 2002 (SFSU, holotype; ZT, isotype). - Figure 4-5.

Pileus $15 \times 20 \mathrm{~mm}$ diam, conical, conical apex not be seen clearly; surface squamules, slightly hygrophanous; margin incurved, becoming decurved in age; brown. Lamellae adnexed or sinuate, close with 2 series of lamellulae, broad, concolorous with pileus. Stipe $90-120 \times$ 4-6 mm, central, terete, equal or slightly tapering towards the apex, surface dry, glabrous with finely pruinose, base slightly bulbous, light brown. Context thin, off-white to pale brown. Odor and taste not distinctive.

Basidiospores (8.8) 9.6-12(13.6) × (8.8)9.6-12 $\mu \mathrm{m}\left(\mathrm{x}_{\mathrm{m}}\right.$ $=11.49 \pm 0.98 \times 10.94 \pm 0.92, \mathrm{Q}=1.00-1.15, \mathrm{Q}_{\mathrm{m}}=1.05 \pm$ $0.06, \mathrm{n}=25$ spores per 1 specimen), echinulate, with conical projections up to $5 \mu \mathrm{m}$, globose or subglobose, slightly thick-walled, pale brown. Basidia 34.4-62 $\times$ 12-13.6 $\mu \mathrm{m}$, clavate, bearing 4-spored. Basidioles clavate. Hymenial cystidia 36-88 × 14.4-20 $\mu \mathrm{m}$, broadly fusoid, metuloid, thin to thick-walled up to $4.0 \mu \mathrm{m}$, hyaline. Pileipellis cutis; hyphae $6-8 \mu \mathrm{m}$ wide, thin-walled, hyaline to yellowish-brown, slightly incrusted. Stipe tissue monomitic; cortical hyphae 4.0-9.6 $\mu \mathrm{m}$ diam, parallel, cylindrical, thick-walled up to $3.2 \mu \mathrm{m}$, inamyloid, yellowish-brown; medullary hyphae $3.2-4.8 \mu \mathrm{m}$ diam, thin-walled, inamyloid, hyaline to slightly yellowishbrown. Caulocystidia similar to hymenial cystidia, 36-52 $\times$ 16-21.6 $\mu \mathrm{m}$, broadly fusoid, metuloid, thin to thick-walled up to $4.0 \mu \mathrm{m}$, hyaline. Clamp connection present.

Table 1. Variations of morphological characters of Mycena picta from different areas.

\begin{tabular}{|c|c|c|c|c|}
\hline Characters & Indonesia & $\begin{array}{c}\text { Finland } \\
\text { (Harmaja 1979) }\end{array}$ & $\begin{array}{c}\text { Japan } \\
\text { Miyamoto et al. 1996) }\end{array}$ & $\begin{array}{c}\text { Poland } \\
\text { (Halama and Romański } \\
\text { 2010) }\end{array}$ \\
\hline Pileus (mm in diam) & $2-4$ & $2-4$ & $2.5-4$ & $1.5-6.5$ \\
\hline Pileus high (mm) & $2-4$ & $3-6$ & $2-4$ & $2.0-7.0$ \\
\hline The number of lamellae (lamellae) & 22 & - & $5-18$ & $19-22$ \\
\hline Stipe (length $\mathrm{x}$ width $(\mathrm{mm})$ ) & $30-43 \times 0.5$ & $20-30 \times 0.5-1$ & $18-27 \times 0.4-0.7$ & $8-61 \times 0.5-0.9$ \\
\hline Basidiopores (length $\mathrm{x}$ width $(\mu \mathrm{m})$ ) & $7.2-8.8 \times 4.0-4.8(5.6)$ & $6.0-8.0 \times 3.5-4.2$ & $(5.6-) 6.4-9.4(-1) \times(2.6-) 3.3-5.2$ & $6.8-7.3(7.9) \times(3.0) 4.0-4.3(4.7)$ \\
\hline Pleurocystidia $(\mu \mathrm{m})$ & $28-40 \times 4.0-4.8(5.6)$ & not mentioned & not seen & Pleurocystidia absent \\
\hline Cheilocystidia $(\mu \mathrm{m})$ & $\begin{array}{l}\text { Siccus-type broom } \\
\text { cells }\end{array}$ & $\begin{array}{l}\text { Siccus-type } \\
\text { broom cells }\end{array}$ & Siccus-type broom cells & Siccus-type broom cells \\
\hline
\end{tabular}



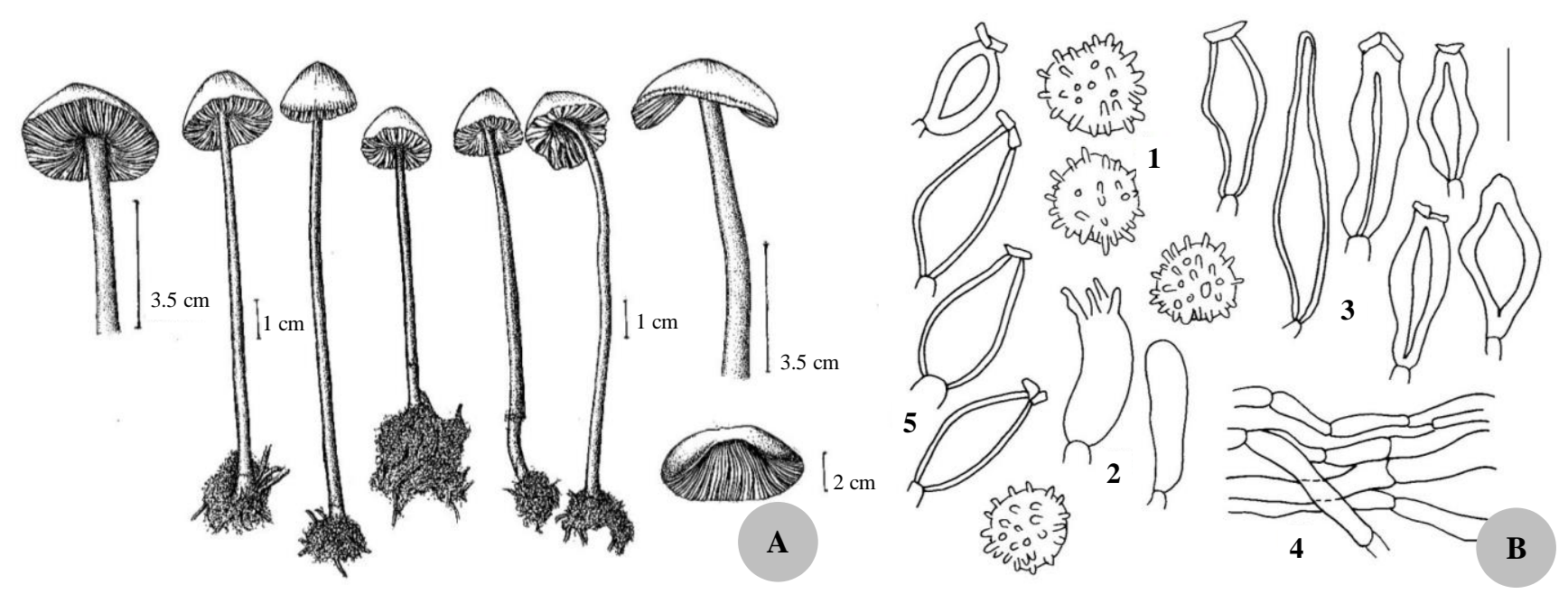

Figure 5. Inocybe stellata: A. Morphological characters of fruiting body (Drawn by A. Kusumawaty); B. Microscopic characters: 1. Basidiospores; 2. Basidia and Basidioles; 3. Hymenial cystidia; 4. Pileipellis; 5. Caulocystidia. Scale bar: B1 = $15 \mu \mathrm{m}$; B2-B5 = 30 $\mu \mathrm{m}$. Drawn by A. Retnowati from Banggai 08 .

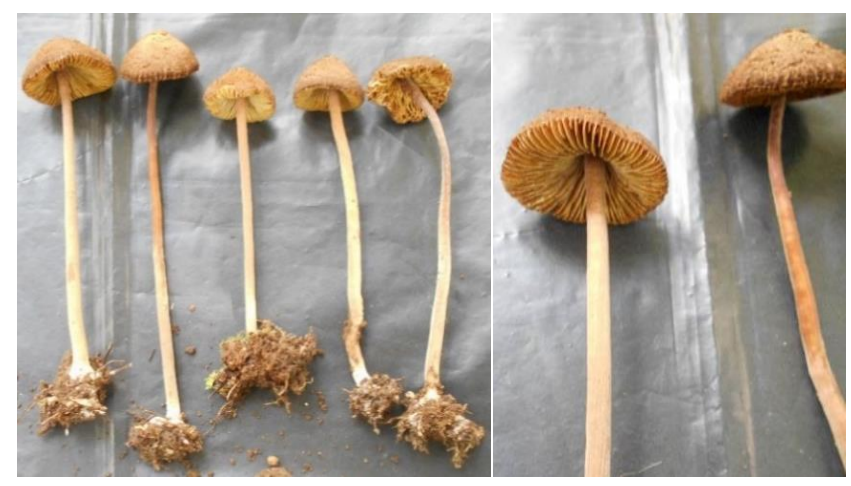

Figure 4. Inocybe stellata: 1. Fresh materials of fruiting body with brown pileus; 2. Lamellae and lamellulae (Photograps by: Idang Sumantha)

Habit, habitat, and distribution. Solitary to gregarious on the soil in forest. Banggai Kepulauan (Sulawesi).

Material examined. Indonesia: Sulawesi, Central Sulawesi, Banggai Kepulauan, Peleng Island, Kautu Hill, Desa Salakan, Kecamatan Tinangkung, 29 June 2019, Banggai 08, collected by Idang Sumanta.

Notes. Inocybe stellata belongs to the family Inocybaceae. The species was originally described from Thailand and it occurred on lateritic soil (in recently burned) tropical lowland forest (dominated by Dipterocarpus obtusifolia, mixed with Tectona grandis) (Horak et al. 2015). This I. stellata is distinguished by having conical and squamules pileus. The characters of the Indonesian material confirm that is I. stellata. However, the conical apex is usually distinctive character of the species, but it can not be seen clearly in Indonesian material. The closest species to the I. stellata is I. petchii. The latter species is having bigger pileus up to $60 \mathrm{~mm}$, papilla umbo present, a small bulb, and longer stipe up to $200 \mathrm{~mm}$.
In conclusion, two species of Agaricales from Banggai Kepulauan, Sulawesi were identified as $M$. picta and $I$. stellata based on morphological characters. Both were new records for Indonesia. More studies of other materials from Banggai will yield more species of Agaricales, either as a new species or new record. The result of the taxonomic study of the Agaricales in these archipelago becomes one of the important data for making conservation decisions.

\section{ACKNOWLEDGEMENTS}

The authors greatly thank Idang Sumanta who collected materials from research sites. Kusuma Rahmawati and a team of Biodiversity Survey, Research Center for Biology to Banggai Kepulauan are also thanked for who made the fieldwork possible. The authors are also indebted to Prof. Egon Horak who compared the description of Indonesia collection with the protologue of I. stellata in order to ensure the correct identification of the species. The survey was funded by The Indonesian Government to LIPI.

\section{REFERENCES}

Arnolds E, Veerkamp M. 2008. Basis rapport Rode Lijst Paddenstoelen. Nederlandse Mycologische Vereniging, Utrecht.

Badan Informasi Geospasial Republik Indonesia. 2015-2019. Peta Rupabumi Digital Indonesia. Bogor, Jawa-Barat. [Indonesian]

Benkert D, Dörfelt H, Hardtke HJ, et al. 1992. Rote Liste der gefährdeten Großpilze in Deutschland. Deutsche Gesellschaft für Mykologie e.V. \& Naturschutzbund Deutschland e.V. (NABU), IHW-Verlag, Eching.

Boedijn KB. 1940. Mycetozoa, fungi, and lichenes of the Krakatau Group. Bulletin du Jardin Botanique de Buitenzorg 16: 398-399.

Bujakiewicz A. 2002. New, rare and endangered fungi in the Bialowieża Primeval Forest (E Poland). Polish Bot J 47 (2): 113-124.

Corner EJH. 1994. Agarics in Malesia. I. Tricholomatoid. II. Mycenoid. Beih Nova Hedwigia 109: 165-271.

Desjardin DE, Retnowati A, Horak E. 2000. Agaricales of Indonesia. 2. A preliminary monograph of Marasmius from Java and Bali. Sydowia 52 (2): $92-93$ 
Halama M, Romański M. 2010. A new record of Mycena picta (Fr.: Fr.) Harmaja (Agaricales, Basidiomycota) from the Wigierski National Park (NE Poland). Opole Sci Soc Nat J 43: 29-36.

Harmaja H. 1979. Mycena picta n. comb., an agaric new to Finland. Karstenia 19: 52-53

Hennings P. 1900. Fungi monsunenses. Monsunia 1: 15-16; 1: 150-151

Hibbet DS, Binder M, Bischoff JF, et al. 2007. A higher-level phylogenetic classification of the Fungi. Mycol Res 111: 509-547.

Horak E, Matheny PB, Desjardin DE, et al. 2015. The genus Inocybe (Inocybaceae, Agaricales, Basidiomycota) in Thailand and Malaysia. Phytotaxa 230 (3): 201-238. DOI: 10.11646/ phytotaxa.230.3.1

Horak E. 1980. Inocybe (Agaricales) in Indomalaya and Australasia. Persoonia 11 (1): 1-37.

Kirk PM, Cannon PF, Minter DW. 2008. Ainsworth and Bisby's Dictionary of the Fungi, 10th ed. CAB International, Wallingford UK.

Kornerup A, Wanscher JH. 1978. Methuen Handbook of Colour. 3rd. ed. Eyre Methuen, London.

Largent DL, Baroni TJ. 1988. How to Identify Mushrooms to Genus IV: Modern Genera. Mad River Press, Eureka, California

Latha KDP, Manimohan P. 2017. Inocybes from Kerala. SporePrint Books, Calicut, India.

Léveillé JH. 1844. Champignons exotiques. Annales des Sciences Naturelles (Paris), 3. sér., 2: 167-221.

Léveillé JH. 1846. Descriptions des Champignons de l'Herbier du Muséum de Paris. Annales des Sciences Naturelles (Paris) 5: 111167.

Maas Geesteranus RA. 1983. Studies in Mycenas. Proceedings of the Koninklijke Nederlandse Akademie van Wetenschappen Section C 86 (3): 385-399.

Matheny PB, Aime MC, Bougher NL, et al. 2009. Out of the palaeotropics? Historical biogeography and diversification of the cosmopolitan mushroom family Inocybaceae. J Biogeogr 36: 577 592.

Matheny PB, Aime MC, Smith ME, Henkel TW. 2012. New species and reports of Inocybe (Agaricales) from Guyana. Kurtziana 37 (1): 23 39.

Miyamoto T, Cha JY, Igarashi T. 1996. A new record of Mycena picta from Japan. Mycoscience 37: 463-466.

Moritzi A. 1845-1846. Verzeichnis der von H. zollinger in den Jahren 1842-1844 auf Java gesammelten Pflanzen, nebst einer kurzen
Beschreibung der neuen Gattungen und Arten. Solothurn. Verf. Phyt. $467 \mathrm{~d}$

Overeem C van, Overeem-de Haas D van. 1922. Verzeichnis der in Niederländisch Ost Indien bis dem Jahre 1920 gefundenen Myxomycetes, Fungi, und Lichens. Bulletin du Jardin Botanique de Buitenzorg 3 (4): 88-89.

Pegler DN. 1977. A preliminary agarics flora of East Africa. Kew Bull Addit Ser 6: 1-615.

Pegler DN. 1983. Agarics flora of Lesser Antilles. Kew Bull Addit Ser 9: 195-232.

Pegler DN. 1986. Agarics flora of Sri Lanka. Kew Bull Addit Ser 12: 144172.

Pradeep CK, Vrinda KB, Varghese SP, Korotkin HB, Matheny PB. 2016. New and noteworthy species of Inocybe (Agaricales) from tropical India. Mycol Progr 15: 24

Rahmadi C, Haryoko T, Riyanto A, et al. 2014. Laporan Akhir Inventarisasi Flora dan Fauna Kabupaten Banggai Kepulauan. Salakan: Badan Pengelolaan Lingkungan Hidup Kabupaten Banggai Kepulauan \& Pusat Penelitian Biologi-LIPI. [Indonesian]

Retnowati A. 2018. The species of Marasmiellus (Agaricales: Omphalotaceae) from Java and Bali. Gard Bull Sing 70 (1): 191-258. DOI: $10.26492 / \mathrm{gbs} 70(1) .2018-17$.

Ryvarden L. 1990. Aphylloporales: Ganodermataceae, Hymenochaetaceae and Polyporaceae. In: GJ Samuels (ed.), Contributions toward a mycobiota of Indonesia: Hypocreales, synnematous Hyphomycetes, Aphyllophorales, Phragmobasidiomycetes, and Myxomycetes. New York Botanical Garden, New York.

Samuels GJ, Doi Y, Farr ML. 1990. Contributions toward a mycobiota of Indonesia: Hypocreales, synnematous Hyphomycetes, Aphyllophorales, Phragmobasidiomycetes, and Myxomycetes. New York Botanical Garden, New York.

Shiryaeva OS. 2018. New records of agaricoid fungi from Sverdlovsk region, Russia. Botanica 24 (2): 150-161.

Singer R. 1975. The Agaricales in Modern Taxonomy. 3 ed. Verlag J. Cramer, Vaduz.

Singer R. 1986. The Agaricales in Modern Taxonomy. 4 ed. Koeltz Scientific Book, Germany.

Zollinger H. 1844. Observationes phytogeographicae praecipue genera et species nova nonnulla. Natuur Geneesk. Architecture ned Indie, D 1. 1: 372-405 